\title{
Antioxidant capacity and composition of pitanga seeds
}

\author{
Capacidade antioxidante e composição de sementes de pitanga
}

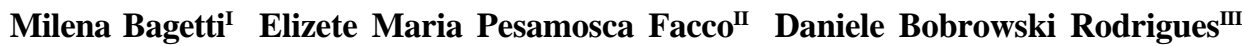 \\ Márcia Vizzotto ${ }^{\mathrm{IV}}$ Tatiana Emanuelli ${ }^{\mathrm{II}}{ }^{*}$
}

\begin{abstract}
Food industry generates a significant amount of seed wastes from the juice production, frozen pulps and jams. Considering that the characterization of wastes is the first step to determine their potential use, the aim of the present study was to determine the composition and the antioxidant capacity of seeds from pitanga fruits with different flesh colors (purple, red and orange). Chemical composition results revealed that pitanga seeds are a good source of insoluble dietary fiber, with low protein and fat levels, and no relevant differences were found among pitanga seeds from different flesh colors. Pitanga seed extracts had powerful antioxidant capacity that was partially correlated to their high phenolic content and showed some variation according to the pitanga flesh colors. Accordingly, it's suggested that this low value waste of pitanga processing, could be used as a source of natural antioxidants and dietary fiber, for animal and/or human nutrition.
\end{abstract}

Key words: antioxidant capacity, DPPH, FRAP, Eugenia uniflora $L$.

\section{RESUMO}

A indústria de alimentos gera quantidades significativas de resíduos de sementes a partir da produção de sucos, polpas congeladas e geleias de frutas. Considerando que a caracterização dos resíduos é o primeiro passo para determinar o seu uso potencial, o objetivo do presente estudo foi determinar a composição e a capacidade antioxidante de sementes de pitanga com diferentes colorações de polpa (roxa, vermelha e laranja). Os resultados da composição química revelaram que as sementes de pitanga são boas fontes de fibra alimentar insolúvel, com níveis baixos de proteína e gordura, e sem diferenças relevantes entre as sementes de pitangas de diferentes colorações. Os extratos das sementes apresentaram uma excelente capacidade antioxidante, que foi parcialmente correlacionada com o alto teor de fenólicos e apresentou alguma variação de acordo com a coloração da polpa das pitangas. Assim, sugere-se que esse resíduo de baixo valor, resultante do processamento da pitanga, poderia ser utilizado como fonte de antioxidantes naturais e de fibra alimentar, para a nutrição humana e/ou animal.

Palavras-chave: capacidade antioxidante, DPPH, FRAP, Eugenia uniflora $L$.

\section{INTRODUCTION}

The Brazilian cherry or pitanga (Eugenia uniflora) is a member of the Mirtaceae family. Mirtaceae is a pan-tropical family that occurs in South America, Southeast Asia, and Australia. Many species of Myrtaceae, including pitanga, are cultivated in home gardens for their edible fruit, and their leaves have been used in traditional medicine to treat several inflammatory conditions (REYNERSTON et al., 2008). In the Brazilian food industry, pitanga fruits have mostly been used to produce juice and frozen pulp.

Fruits are known as important sources of bioactive compounds. The pitanga frozen pulp has high content of total phenolics and carotenoids, which are known as antioxidant compounds (SPADA et al., 2008). Concerning to the phenolic compounds, the aqueous

'Programa de Pós-graduação em Ciência e Tecnologia de Alimentos, Universidade Federal de Santa Maria (UFSM), Santa Maria, RS, Brasil. "Universidade de Caxias do Sul (UCS), Caxias do Sul, RS, Brasil.

IIINúcleo Integrado de Desenvolvimento em Análises Laboratoriais (NIDAL), Departamento de Tecnologia e Ciência dos Alimentos, UFSM. Av. Roraima, n.1000, Bairro Camobi, 97105-900, Santa Maria, RS, Brasil. E-mail: tatiemanuelli@smail.ufsm.br. *Autor para correspondência.

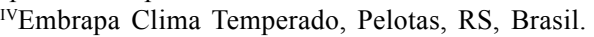


fraction of pitanga fruits contains antioxidant anthocyanins (cyanidin-3-O- $\beta$-glucopyranoside and delphinidin-3-O- $\beta$-glucopyranoside; EINBOND et al., 2004). Besides, the essential oil from pitanga fruits contains $\beta$-ocimene $(7.4 \%), \alpha$-selinene $(7.2 \%), \beta$ selinene $(5.2 \%)$, germacrene B $(7.2 \%)$ and hexadecanoic acid $(11.7 \%)$ and was demonstrated to have an interesting antioxidant activity (MARIN et al., 2008). However, few studies were found on bioactive compounds from pitanga seeds (OLIVEIRA et al., 2008).

Worldwide several million tons of agri-food solid wastes are produced annually and are likely to be discarded or used as low-value by-products (TALCOTT et al., 2003; ISCI \& DEMIRER, 2007). Food industry generates a significant amount of seed wastes from the production of juice nectars, concentrates, jams, jelly powders and fruit bars. These wastes could be used as a source of ingredients for the food industry, since many fruit seeds have high content of antioxidant phenolic compounds (PURAVANKARA et al., 2000), dietary fiber (AL-FARSI \& LI, 2008), oils (KOBORI \& JORGE, 2005) and other components. This practice would reduce the impact on the environment, besides yielding value added ingredients (EMBRAPA INFORMAÇÃO TECNOLÓGICA, 2003).

Fruit seeds have not generally received much attention as antioxidant sources, however SOONG \& BARLOW (2004) demonstrated a significantly higher phenolic content and total antioxidant capacity in the seeds of fruits than in their edible portions. Antioxidants from residual sources could be used as natural food additives to increase the stability of foods by preventing lipid oxidation (MOURE et al., 2001). Besides its antioxidant capacity, phenolic compounds, mainly phenolic acids and flavonoids, possess other interesting health beneficial properties like anti-carcinogenic (BAILEY \& WILIAMS, 1993), antimicrobial (TAKECHI et al., 1985), anti-mutagenic (LIVERIO et al., 1994) and antiinflammatory activities (LANDOLFI et al., 1984), which could be exploited by the pharmaceutical industry.

Besides phenolic compounds, some fruit seeds contain other nutritionally important compounds that are usually underutilized. Blackcurrant or groselha (Ribes nigrum) seeds contain an exceptionally high level of the desirable polyunsaturated $\gamma$-linolenic acid (TRAITLER et al., 1984), while seeds of date have a high content of dietary fiber (AL-FARSI \& LEE, 2008).

In the literature no data was found concerning to the composition or antioxidant capacity of pitanga seeds. Considering that the characterization of wastes is the first step to establish their potential use, the aim of the present study was to determine the composition and the antioxidant capacity of seeds from pitanga fruits with different flesh colors (purple, red and orange). These fruits were from trees cultivated at Embrapa Clima Temperado (RS, Brazil) and are being studied to yield cultivars adapted to the Brazil southern region 1 .

\section{MATERIAL AND METHODS}

Samples

The samples of purple, red and orange fleshed pitanga fruits (Eugenia uniflora L.), were harvested at Embrapa Clima Temperado (Rio Grande do Sul, Brazil) in 2007. Each sample was a mixture of completely ripe fruits from various plant selections with the same flesh color. Three independent lots were separated, frozen at $-18^{\circ} \mathrm{C}$ and transported to the Federal University of Santa Maria. Fruits were thawed and the flesh (edible portions) was manually separated from the seeds. Seeds were dried in a conventional air-oven during 4 hours at $60^{\circ} \mathrm{C}$ and then ground using a Wiley grinder with a $2 \mathrm{~mm}$ sieve and stored at $-18^{\circ} \mathrm{C}$ until analysis.

\section{Composition}

Moisture weight loss was determined at $105^{\circ} \mathrm{C}$ (method 925.10; AOAC, 1995). Ash content was determined at $550^{\circ} \mathrm{C}$ (method 923.03) according to AOAC (1995). Protein content $(\mathrm{N} x$ 6.25) was determined by the microkjeldahl procedure (method 960.2$)$ of the AOAC (1995). Total and insoluble dietary fiber was determined by the enzymatic-gravimetric methods (985.29 and 991.42) fromAOAC (1995). Fat was extracted using chloroform and methanol as described by BLIGH \& DYER (1959) and used for determination of the fat content and fatty acid profile. To prevent lipid oxidation during and after extraction, $0.02 \%$ butyl hydroxyl toluene was added to the chloroform used. The nitrogen free extract fraction (Nifext) was calculated by difference.

\section{Fatty acid methyl esters (FAMES)}

Aliquots $(2-3 \mathrm{~mL})$ of the chloroform-lipid extract from BLIGH \& DYER (1959) were evaporated at $50^{\circ} \mathrm{C}$ using a vacuum pump. Fat was saponified in methanolic sulfuric acid solution as described by HARTMAN \& LAGO (1973). Methylated samples were analyzed using an Agilent Technologies gas chromatograph (HP 6880) fitted with a capillary column DB-23 (60m x $0.25 \mathrm{~mm} \times 0.25 \mu \mathrm{m}$, Agilent) and a flame ionization detector. The temperature of the injector port and the detector were set at $250^{\circ} \mathrm{C}$, and the carrier gas was nitrogen $\left(0.6 \mathrm{~mL} \mathrm{~min}^{-1}\right)$. After injection $(1 \mu \mathrm{L}$, split ratio 1:50), the oven temperature was hold at $140^{\circ} \mathrm{C}$ for $5 \mathrm{~min}$, increased to $240^{\circ} \mathrm{C}$ at a rate of $4^{\circ} \mathrm{C} \mathrm{min}-1$ and hold at this temperature for $5 \mathrm{~min}$. 
Phenolic compounds

The extraction of phenolic compounds was performed using the method of ESCARPA \& GONZÁLEZ (2001) modified as follows. The homogenized samples $(2 \mathrm{~g})$ were extracted in an ultrasonic bath at room temperature in the absence of light with an aqueous solution consisted of $800 \mathrm{~mL}$ methanol and $50 \mathrm{~mL}$ formic acid per liter. The samples were sequentially extracted with $6 \mathrm{~mL}$ of the solution for $1 \mathrm{~h}, 6 \mathrm{~mL}$ for $30 \mathrm{~min}$ and $3 \mathrm{~mL}$ for $30 \mathrm{~min}$. After each extraction, the extracts were filtered in qualitative filter paper under vacuum. The combined filtrate was brought to a final volume of $25 \mathrm{~mL}$ with the solution and stored at $-18^{\circ} \mathrm{C}$ until required for analysis.

Total phenolic content was determined using the method of SINGLETON \& ROSSI (1965). An aliquot of $0.1 \mathrm{~mL}$ of extract was mixed with $2.5 \mathrm{~mL}$ of $0.25 \mathrm{~mol}$ per liter Folin-Ciocalteu reagent. After $5 \mathrm{~min}$, $2 \mathrm{~mL}$ of $1 \mathrm{~mol}$ per liter $\mathrm{Na}_{2} \mathrm{CO}_{3}$ was added. The absorbance was determined at $740 \mathrm{~nm}$ after $1 \mathrm{~h}$ in the dark. Gallic acid was used as a standard for the calibration curve. The amount of total phenolic compounds was calculated and expressed as mg gallic acid per $100 \mathrm{~g}$ sample.

Diphenyl-2-picrylhydrazyl (DPPH) radical scavenging assay

A DPPH stable solution was used for determination of the total antioxidant activity of extracts according to BRAND-WILLIAMS et al. (1995). DPPH solution was previously diluted until its absorption at $515 \mathrm{~nm}$ reached $1.10 \pm 0.02$. The extract $(0.05 \mathrm{~mL})$ was mixed with $1.9 \mathrm{~mL}$ diluted methanolic DPPH solution. The antiradical power of the different extracts was determined by measuring the decrease of DPPH absorbance after 24 hours in the dark against a blank. Trolox was used as standard for the calibration curve and the results were expressed as mmol trolox equivalents per $100 \mathrm{~g}$ sample.

Ferric-reducing antioxidant power (FRAP) assay The method of BENZIE \& STRAIN (1996) was used for FRAP assays. Ferric-2,4,6-trypyridyl-striazine (TPTZ) solution was prepared by mixing $2.5 \mathrm{~mL}$ of 10mmol per liter TPTZ solution (prepared in 40mmol per liter $\mathrm{HCl}$ ) with $2.5 \mathrm{~mL}$ of $20 \mathrm{mmol}$ per liter $\mathrm{FeCl}_{3} .6 \mathrm{H}_{2} \mathrm{O}$ and $25 \mathrm{~mL}$ of $0.3 \mathrm{~mol}$ per liter acetate buffer at $\mathrm{pH} 3.6$. The sample $(40 \mu \mathrm{L})$ was mixed with $1.2 \mathrm{~mL}$ of ferric-TPTZ reagent and $120 \mu \mathrm{L}$ of Milli- ${ }^{\circledR}$ water and incubated at $37^{\circ} \mathrm{C}$ during $15 \mathrm{~min}$. The absorbance of the colored complex formed with $\mathrm{Fe}^{+2}$ and TPTZ was taken at $593 \mathrm{~nm}$. Trolox was used as standard for the calibration curve and the results were expressed as mol trolox equivalents per $100 \mathrm{~g}$ sample.
Statistical analysis

The experiment was conducted at a completely randomized design with three groups (colors of pitanga flesh) and three repetitions per group. All measurements were made in triplicate. Results were analyzed by one-way analysis of variance (ANOVA). Post hoc comparisons were made using Tukey's test $(\mathrm{P}<0.05)$. The relationship between phenolic content and antioxidant capacity was evaluated by Pearson's correlation. Statistical analyses were carried out using Statistica 6.0 (Copyright Sta Soft, Inc 1984-2001).

\section{RESULTS AND DISCUSSION}

Seeds chemical composition from purple, red and orange fleshed pitanga was similar (Table 1). No significant difference was observed in the moisture, ash, protein, total carbohydrate, and total and insoluble dietary fiber or Nifext fraction among samples. However, the fat content of seeds from purple fleshed pitanga were lower than that of the other samples $(\mathrm{P}<0.05)$. Seeds moisture content are similar to orange and guava seed wastes (55.4 and 43.3\%, respectively), but much lower than passion fruit (80.9\%; KOBORI \& JORGE, 2005). Carbohydrate was the major nutrient found in pitanga seeds. This fraction was found to be composed mainly by insoluble dietary fiber, with a lower amount of digestible carbohydrates (Nifext fraction). Dietary fiber has important therapeutic implications for certain conditions such as diabetes, cardiovascular diseases and intestinal disorders in humans (SUTER, 2005). The insoluble fraction facilitates gastrointestinal transit and reduces constipation (SUTER, 2005). Besides, complex carbohydrates, like those found in

Table 1 - Chemical composition (g per 100g fresh weight) of seeds from purple, red and orange pitanga (Eugenia uniflora L.).

\begin{tabular}{|c|c|c|c|}
\hline & Purple & Red & Orange \\
\hline Moisture & $57.5 \pm 0.4$ & $58.6 \pm 0.7$ & $57.0 \pm 0.0$ \\
\hline Ash & $0.8 \pm 0.1$ & $0.8 \pm 0.0$ & $0.6 \pm 0.0$ \\
\hline Protein & $3.7 \pm 0.2$ & $3.6 \pm 0.2$ & $3.3 \pm 0.2$ \\
\hline Fat & $0.5 \pm 0.0$ & $0.7 \pm 0.0^{*}$ & $0.7 \pm 0.0^{*}$ \\
\hline Total carbohydrate ${ }^{\&}$ & $37.5 \pm 0.5$ & $36.4 \pm 0.9$ & $38.4 \pm 0.2$ \\
\hline Total fiber & $24.7 \pm 0.1$ & $23.4 \pm 0.1$ & $23.0 \pm 0.1$ \\
\hline Insoluble fiber & $23.7 \pm 0.2$ & $23.3 \pm 0.0$ & $23.0 \pm 0.0$ \\
\hline Nifext fraction ${ }^{\&}$ & $12.8 \pm 0.5$ & $13.0 \pm 0.9$ & $14.4 \pm 0.2$ \\
\hline
\end{tabular}

Results are mean \pm standard deviation $(n=3)$. *Significantly different from purple samples $(\mathrm{P}<0.05)$. ${ }^{\circledR}$ Calculated by difference. 
the dietary fiber fraction, are also very important in the nutrition of ruminants (FOX et al., 1992). Therefore, the insoluble dietary fiber of pitanga seeds could be evaluated for use in human and/or animal nutrition. However, it is important to evaluate if the lectins recently described in pitanga seeds (OLIVEIRA et al., 2008) could be a limiting factor for this application.

Table 2 presents the fatty acid composition of pitanga seeds. Pitanga seeds had a high proportion of unsaturated fatty acids (60-70\%) being $13-16 \%$ monounsaturated fatty acids (MUFA) and 45-47\% polyunsaturated fatty acids (PUFAS). PUFAS, especially the n-3 fatty acids, are considered desirable compounds in the human diet because of their effect in reducing the incidence of cardiovascular disease (LEAF \& WEBER, 1988). Pitanga seeds had MUFA proportion similar to that of black currant seed residue (HELBIG et al., 2008).

In seeds from purple and red pitanga the predominant unsaturated fatty acid was linoleic acid (C18:2n6c), followed by oleic acid (C18:1n9c), while seeds from orange pitanga had á-linolenic acid (C18:3n3) as the second most abundant unsaturated fatty acid. YI et al. (2008) also found linoleic acid as the predominant fatty acid in berry seeds press residues. Palmitoleic acid was found only in seeds from purple and red pitanga. Seeds from purple and red pitanga had higher linoleic acid and lower á-linolenic acid content than seeds from orange pitanga $(\mathrm{P}<0.05)$. Seeds from red pitanga had higher oleic acid $(\mathrm{C} 18: 1 \mathrm{n} 9 \mathrm{c})$ followed by seeds from orange and purple pitanga $(\mathrm{P}<0.05)$.

The only saturated fatty acid found was palmitic acid, which was found in higher proportion in seeds from orange pitanga when compared to the other samples $(\mathrm{P}<0.05)$. Tomato seeds also had high content

Table 2 - Fatty acid composition ( $\%$ of total fatty acids) of seeds from purple, red and orange pitanga.

\begin{tabular}{llll}
\hline Fatty acids & \multicolumn{1}{c}{ Purple } & \multicolumn{1}{c}{ Red } & \multicolumn{1}{c}{ Orange } \\
\hline C16:0 & $29.8 \pm 0.6^{\mathrm{b}}$ & $30.3 \pm 1.7^{\mathrm{b}}$ & $34.2 \pm 0.0^{\mathrm{a}}$ \\
$\mathrm{C} 16: 1 \mathrm{n} 7 \mathrm{c}$ & $1.4 \pm 0.0^{\mathrm{a}}$ & $1.5 \pm 0.1^{\mathrm{a}}$ & $\mathrm{ND}$ \\
$\mathrm{C} 18: 1 \mathrm{n} 9 \mathrm{c}$ & $12.5 \pm 0.5^{\mathrm{c}}$ & $15.0 \pm 0.3^{\mathrm{a}}$ & $13.7 \pm 0.1^{\mathrm{b}}$ \\
C18:2n6c & $38.3 \pm 0.9^{\mathrm{a}}$ & $36.0 \pm 2.0^{\mathrm{a}}$ & $28.6 \pm 0.0^{\mathrm{b}}$ \\
C18:3n3 & $8.7 \pm 0.4^{\mathrm{b}}$ & $9.2 \pm 0.7^{\mathrm{b}}$ & $18.3 \pm 0.0^{\mathrm{a}}$ \\
NI & $9.3 \pm 0.3$ & $8.0 \pm 2.2$ & $5.3 \pm 0.0$ \\
\hline
\end{tabular}

Results are mean \pm standard deviation $(n=3)$. Means that have no common letters within the same row are statistically different $(\mathrm{P}<0.05)$. C12:0, C14:0, C14:1n5, C18:0, C18:1n9t, C18:2n6t C20:1n9, C20:4n6, C20:5n3, C22:0, C22:5n3 and C22:6n3 were not detected. NI: Non-identified compounds. of palmitic acid, but followed by stearic acid (CANTARELI et al., 1993), which was not found in pitanga seeds.

Seeds from orange pitanga had higher phenolic content than seeds from purple and red pitanga (Table $3, \mathrm{P}<0.05$ ). Total phenolic content of pitanga seeds is very similar to that found for jackfruit seed (Artocarpus heterophyyllus Lam.) (SOONG \& BARLOW, 2004) and it is about 5 to 10 -fold higher than that found on grape pomace powder from winemaking industry (YI et al., 2008) or on the edible portion of various fruits (VINSON et al., 2001). Hence, pitanga seeds can be considered good sources of phenolics.

The antioxidant capacity of pitanga seeds was expressed as equivalents of trolox, which is a hydrosoluble analog of vitamin E. Seeds from orange pitanga had slightly higher radical scavenging capacity in the DPPH assay than seeds from purple pitanga $(\mathrm{P}<0.05)$, but both had DPPH values similar to red pitanga (Table 3 ). In contrast, seeds from purple pitanga had higher ferric reducing antioxidant power than all the other samples $(\mathrm{P}<0.05$; Table 3$)$. These screening tests indicate that pitanga seeds appear to be promising sources of antioxidants, since their activity in the DPPH assay was about two-times higher than that presented by the pulp of various tropical fruits including grape, açaí (Euterpe oleracea) and baguaçu (Eugenia umbelliflora Berg) (KUSKOSKI et al., 2006). However, further studies are required to completely characterize the potential of extracts from pitanga seeds as antioxidant additives in foods or in the treatment of free radical-associated disorders.

Generally, a positive relationship between total phenolics and antioxidant activity has been reported previously (ALONSO et al., 2002). In the present study the phenolic content had a positive correlation with antioxidant capacity measured by the DPPH assay $\left(\mathrm{r}^{2}=0.72, \mathrm{P}<0.05\right)$. Although this result suggests a role for phenolic compounds in the scavenging of DPPH radical, further studies on the complete composition of the extracts are required to confirm this hypothesis. In contrast to the DPPH assay, the antioxidant capacity assessed by the FRAP method had no significant correlation with total phenolic content, suggesting that compounds that are not evaluated in the total phenolic assay may be more important to the FRAP antioxidant capacity. Carotenoids are known to be important antioxidant compounds in pitanga flesh (SPADA et al., 2008). However, it is unlikely that pitanga seeds have an appreciable amount of these antioxidant compounds, since they had a white to pale green color. The 
Table 3 - Antioxidant capacity and phenolic content of extracts from purple, red and orange pitanga.

\begin{tabular}{lccc}
\hline Samples & $\begin{array}{c}\text { Phenolic content } \\
\text { (g gallic acid per 100g) }\end{array}$ & DPPH (mmol trolox per 100g) & FRAP (mmol trolox per 100g) \\
\hline Purple & $2.5 \pm 0.2^{\mathrm{b}}$ & $14.6 \pm 0.6^{\mathrm{b}}$ & $26.2 \pm 2.8^{\mathrm{a}}$ \\
Red & $2.6 \pm 0.0^{\mathrm{b}}$ & $16.7 \pm 1.3^{\mathrm{a}, \mathrm{b}}$ & $6.1 \pm 0.7^{\mathrm{b}}$ \\
Orange & $2.8 \pm 0.2^{\mathrm{a}}$ & $17.4 \pm 1.4^{\mathrm{a}}$ & $6.4 \pm 0.4^{\mathrm{b}}$ \\
\hline
\end{tabular}

Results are mean \pm standard deviation $(\mathrm{n}=3)$ and are expressed per $100 \mathrm{~g}$ of dried seed used to prepare the extract. DPPH: 1,1-diphenyl-2picrylhydrazyl; FRAP: ferric reducing antioxidant power. Means that have no common letter within the same column are different $(\mathrm{P}<0.05)$.

discrepancy between results of DPPH and FRAP assay may be related to the different mechanisms involved in each evaluation. In the FRAP assay the antioxidant capacity is measured as the ability to reduce $2,4,6$ trypyridyl-s-triazine-Fe(III) complex to 2,4,6-trypyridyls-triazine-Fe(II) complex (BENZIE \& STRAIN, 1996) and may be related to the presence of iron-chelating compounds in the samples. In contrast, the DPPH assay involves a fast electron transfer process from phenolic compounds to the DPPH radical (BRANDWILLIAMS et al., 1995; MARTINS et al., 2009). In a recent study MARTINS et al. (2009) showed that results of DPPH were more correlated to the antioxidant capacity of compounds in situ, than the FRAP assay.

Flavonoids are considered the most powerful antioxidants among the polyphenol compounds (SHAHID et al., 1992; SOOBRATTEE et al., 2005). LU \& FOO (2003) showed the presence of an array of polyphenols in blackcurrant seeds, such as anthocyanins, consisting of the rutinosides and glucosides of delphinidin, cyanidin, myricetin, quercetin, kaempferol, dihydroquercetin and aureusidin, as well as the phenolic acids 1-cinnamoyland 1-p-coumaroyl-b-D-glucosides. Thus, it is possible that flavonoid compounds could be the major responsible for the antioxidant capacity of pitanga seeds. However, more studies are needed to identify the phenolic profile of pitanga seeds.

\section{CONCLUSIONS}

Pitanga seeds had powerful antioxidant capacity that was partially correlated to their high phenolic content and showed some variation according to the pitanga flesh colors. Accordingly, we suggest that this low value waste of pitanga processing, could be used as a source of natural antioxidants. No relevant differences were found in the composition among seeds from pitanga of different colors. Results revealed that pitanga seeds are a good source of insoluble dietary fiber, which could be explored for use in animal and/or human nutrition. However, more studies are necessary to determine if some antinutritional factor like cyanogenic glycosides or lectins could be a limitant factor for this application.

\section{ACKNOWLEDGEMENTS}

Authors acknowledge Embrapa Clima Temperado of Pelotas-RS for the samples of pitanga. Tatiana Emanuelli is the recipient of CNPq research Fellowship. Milena Bagetti is the recipient of a CAPES Master Degree fellowship. This study was supported by Edital Casadinhos (FAPERGS/CAPES) to PPGCTA-UFSM.

\section{REFERENCES}

AL-FARSI, M.; LEE C.Y. Optimization of phenolics and dietary fiber extraction from date seeds. Food Chemistry, v.108, p.977985, 2008. Disponível em: <http://www.sciencedirect.com/ science?_ob=MImg\&_imagekey=B6T6R-4RBYG2H-6F\&_cdi $=5037 \&$ user $=972058 \&$ orig $=$ search\&_coverDa te $=06 \% 2 \mathrm{~F} 01 \% 2 \mathrm{~F} 2008 \&$ sk $=998919996 \%$ view $=\mathrm{c} \& \mathrm{wchp}=\mathrm{dGLbVlW}-$ zSkWb\&md5 $=3$ b13672ed22a5ba0ca399217948fd6ae \&ie $=/$ sdarticle.pdf>. Acesso em: 17 jun. 2009. doi:10.1016/ j.foodchem.2007.12.009.

ALONSO, A.M. et al. D etermination of antioxidant activity of wine byoproducts and its correlation with plyphenolic content. Journal of Agricultural and Food Chemistry, v.50, p.5832-5836, 2002. Disponível em: http://pubs.acs.org/ doi/pdf $/ 10.1021 / \mathrm{jf025683b}$ ?cookieSet=1. Acesso em: 17 jun. 2009. doi: $10.1021 / \mathrm{jf025683b}$.

AOAC. Association of Official Analytical Chemists. Official methods of analysis of the association of the official analysis chemists. 16.ed. Arlington,1995. 1750p.

BAILEY, G.S.; WILLIAMS, D.E. Potential mechanisms for food related carcinogens and anti-carcinogens. Food Technology, v.47, p.105-118, 1993.

BENZIE, F.F.I.; STRAIN, J.J. The ferric reducing ability of plasma (FRAP) as a Measure of "antioxidant power": the FRAP assay. Analytical Biochemistry, v.239, p.70-76, 1996. Disponível em: <http://www.sciencedirect.com/ science? ob=MImg \& imagekey=B6W9V-45N4P63-78$1 \& \_c d i=6692 \& \_u s e r=972058 \&$ orig $=$ search\&_coverDate $=07$ \%2F $15 \% 2 \mathrm{~F} 1996 \overline{6} \&$ sk $=997609998$ \& view $=\mathrm{c} \& \mathrm{wchp}=\mathrm{dGLbVtz}-$ zSkzk\&md5=df362 fb08932647117081913e3e171eb\&ie =/ sdarticle.pdf $>$. Acesso em: 20 jun. 2009. doi:10.1006/ abio.1996.0292.

Ciência Rural, v.39, n.8, nov, 2009. 
BLIGH, E.G.; DYER, W.J. A rapid method of total lipid extraction and purification. Canadian Journal Biochemistry and Physiology, v.37, p.911-917, 1959. Disponível em: <http://rparticle.webp.cisti.nrc.ca/rparticle/ Abstract TemplateServlet? caly Lang=eng\& jo urnal $=$ cjpp $\&$ volume $=37 \&$ year $=1959 \&$ issue $=8 \&$ msno $=y 59$ 099>. Acesso em: 20 jun. 2009. doi: 10.1139/y59-099.

BRAND-WILLIAMS, W. et al. Use of a free radical method to evaluated antioxidant activity. Lebensmittel-Wissenschaft und-Technologie, v.28, p.25-30, 1995. Disponível em: < http://www.sciencedirect.com/ science?_ob=MImg\&_imagekey=B6WMV-4FJ2FY 9-8 $1 \&$ cdi $=6944 \&$ user $=972058 \&$ orig $=$ search $\&$ coverDate $=$ $12 \% 2 \mathrm{~F} 31 \% 2 \mathrm{~F} 1995 \&$ \&k=999719998\& view=c\&wchp=dGLbVtzzSkzk\&md5=653ae435877c172c5b9f9964aaee0839\&ie=/ sdarticle.pdf $>$. Acesso em: 20 jun. 2009. doi:10.1016/S00236438(95)80008-5.

CANTARELI, P.R. et al. Physicochemical characteristics and fatty acid composition of tomato seed oils from processing wastes. Scientia Agricola, v.50, p.117-120, 1993. Disponível em: $<$ http://www.scielo.br/scielo.php? pid=S0103$90161993000100016 \&$ script $=$ sci arttext\&tlng $=$ en $>$. Acesso em: 17 jun. 2009 . doi: 10.1590/S0103-90161993000100016

EMBRAPA INFORMAÇÃO TECNOLÓGICA. Iniciando um pequeno grande negócio agroindustrial: polpa e suco de fruta. Brasilia: Embrapa Agroindústria de Alimentos, 2003. $123 p$.

EINBOND, L.S. et al. Anthocyanin antioxidants from edible fruits. Food Chemistry, v.84, p.23-28, 2004. Disponível em: <http://home.earthlink.net/ phytochemistry/archive/ einbond.pdf>. Acesso em: 17 jun. 2009. doi:10.1016/S03088146(03)00162-6.

ESCARPA, A.; GONZALEZ, M.C. Approach to the content of total extractable phenolic compounds from different food samples by comparison of chromatographic and spectrophotometric methods. Analytica Chimica Acta, v.427, p.119-127, 2001. Disponível em: <http://www.sciencedirect.com/ science?_ob=MImg\&_imagekey=B6TF 4-41TMP0N-GC\& cdi $=5216 \&$ user $=972058 \&$ orig $=$ search $\&$ coverDate $=01 \% 2 \mathrm{~F} 19 \%$ $2 \mathrm{~F} 2001 \&$ sk $=995729998 \& \mathrm{view}=\mathrm{c} \& \mathrm{w} \mathrm{chp}=\mathrm{dGLbVzW}-$ zSkzk\&md $5=$ bcee $119 \mathrm{e} 3134 \mathrm{c} 749 \mathrm{ddfa} 1 \mathrm{f} 02 \mathrm{dc} 95 \mathrm{cfa} 4 \& \mathrm{ie}=$ sdarticle.pdf $>$. Acesso em: 20 jun. 2009. doi: 10.1016/S00032670(00)01188-0.

FOX, D.G. et al. A net carbohydrate and protein system for evaluating cattle diets: III. Cattle requirements and diet adequacy. Journal of Animal Science, v.70, p.3578-3596, 1992. Disponível em: http://jas.fass.org/cgi/content/abstract/70/11/ 3578. Acesso em: 20 jun. 2009 .

HARTMAN, L; LAGO, R.C.A. A rapid preparation of fatty methyl esters from lipids. Laboratory Practice, v.22, p.475477, 1973.

HELBIG D. et al. Berry seed press residues and their valuable ingredients with special regard to black currant seed press residues. Food Chemistry, v.111, p.1043-1049, 2008. Disponível em: <http://www.sciencedirect.com/ science?_ob=MImg\&_imagekey=B6T6R-4SH0Y 55-J$5 \&$ cdi $=5037 \&$ user $=972058 \&$ orig $=$ search $\&$ coverDate $=12 \% 2 \mathrm{~F} 15$ $\%$ 2 F 2008 \& $\quad$ sk $=998 \overline{8} 89995 \& \mathrm{v}$ i e w $=\mathrm{c} \& \mathrm{wchp}$ $=\mathrm{dGLbVzbzSkWA \&} \& \mathrm{md} 5=\mathrm{a} 9963 \mathrm{~b} 8 \mathrm{e} 7362 \mathrm{ebb} 516222 \mathrm{~d} 245 \mathrm{a} 2696 \mathrm{fc} \& \mathrm{ie}=$ sdarticle.pdf $>$. Acesso em: 12 fev. 2009. doi:10.1016/ j.foodchem.2008.05.017.
ISCI, A.; DEMIRER, G.N. Biogas production potential from cotton wastes. Renewable Energy, v.32, p.750-757, 2007. Disponível em: <http://www.sciencedirect.com/ science? ob=MImg\& imagekey=B6V4S-4K7NHHK-1 C\&_cdi $=5766 \&$ user $=972058 \&$ orig $=$ search\& co verDate $=04 \% 2 \mathrm{~F} 30 \% 2 \mathrm{~F} 2007 \&$ sk=999679994\&view=c\&wchp=dGLzVlzzSkzV\&md5=a8e407bca 8ff8bd21 de0b1 f43ed $18 \mathrm{ac} 2 \& \mathrm{ie}=/$ sdarticle.pdf $>$. Acesso em: 20 jun. 2009. doi: 10.1016/ j.renene.2006.03.018.

KOBORI, C.; JORGE, N. Caracterização dos óleos de algumas sementes de frutas como aproveitamento de resíduos industriais. Ciência e Agrotecnologia, v.29, p.1008-1014, 2005.

KUSKOSKI, E.M. et al. Frutas tropicais silvestres e polpas de frutas congeladas: atividade antioxidante, polifenóis e antocianinas. Ciência Rural, v.36, p.1283-1287, 2006. Disponível em: <http:/ $/$ www.scielo.br/scielo.php?script $=$ sci arttext\&pid $=\mathrm{S} 0103$ $84782006000400037>$. Acesso em: 20 jun. 2009. doi: 10.1590/ S0103-84782006000400037.

LANDOLFI, R. et al. Modification of platelet function and arachidonic acid metabolism by bioflavonoids. Biochemical Pharmacology, v.33, p.1525-1530, 1984

LEAF, A.; WEBER, P.C. Cardiovascular effects of n-3 fatty acids. New England Journal of Medicine, v.318, p.549$557,1988$.

LIVERIO, L. et al. Antimutagenic activity of procyanidins from Vitis vinifera. Journal for the Study of Medicinal Plants, v.65, p.203-209, 1994.

LU, Y.; FOO, Y. Polyphenolic constituents of blackcurrant seed residue. Food Chemistry, v.80, p.71-76, 2003. Disponível em: $<\mathrm{ht} \mathrm{t} \mathrm{p} \mathrm{://} \mathrm{w} \mathrm{w} \mathrm{w.} \mathrm{s} \mathrm{c} \mathrm{i} \mathrm{e} \mathrm{n} \mathrm{c} \mathrm{ed} \mathrm{i} \mathrm{re} \mathrm{c} \mathrm{t} \mathrm{c} \mathrm{o} \mathrm{m/}$ science?_ob=MImg\&_imagekey=B6T6R-470TYP4D3\&_cdi $=5037 \&$ user $=972058 \&$ orig $=$ search\&_coverDate $=$ $01 \% 2$ F $31 \% 2$ F 2003 \& s k = 999 199998 \& $\mathrm{v}$ i e w $=\mathrm{c} \& \mathrm{w}$ c h p $=\mathrm{d}$ G L b V 1 z z S k Wb\&md $5=09 \mathrm{~b} 35$ f0e 4864 d 7425 af 43 ef 4 aa 61 d $562 \&$ ie $=/$ sdarticle.pdf>. Acesso em: 20 jun. 2009. doi: 10.1016/S03088146(02)00239-X.

MARIN R. et al. Volatile components and antioxidant activity from some Myrtaceous fruits cultivated in Southern Brazil. Latin American Journal of Pharmacy, v.27, p.172-177, 2008. Disponível em: http://www.latamjpharm.org/trabajos/ 27/2/LAJOP $27 \quad 2 \quad 1 \quad 2$ TCW8BTA1YY.pdf. Acesso em: 21 jun. 2009.

MARTINS, D.M. et al. Antioxidant potential of new pyrazoline derivatives to prevent oxidative damage. Basic \& Clinical Pharmacology \& Toxicology, v.104, p.107-112, 2009. Disponível em: http://www3.interscience.wiley.com/cgi-bin/ fulltext/121576726/PDFSTART. Acesso em: 21 jun. 2009. doi: $10.1111 / \mathrm{j} .1742-7843.2008 .00346 . x$.

MOURE, A. et al. Natural antioxidants from residual sources. Food Chemistry, v.72, p.145-171, 2001. Disponível em: $<\mathrm{h} \mathrm{t} \mathrm{t} \mathrm{p} \mathrm{:} \mathrm{/} \mathrm{/} \mathrm{w} \mathrm{w} \mathrm{w.} \mathrm{s} \mathrm{c} \mathrm{i} \mathrm{e} \mathrm{n} \mathrm{c} \mathrm{e} \mathrm{d} \mathrm{i} \mathrm{re} \mathrm{c} \mathrm{t} \mathrm{.} \mathrm{c} \mathrm{o} \mathrm{m/}$ science?_ob=M Img \&_im age key=B 6 T 6 R $41 \mathrm{Y} 28407 \&$ cdi $=5037 \&$ user $=972058 \&$ orig $=$ search \& coverDate $=02 \% 2$ F $28 \% 2$ F $2001 \&$ sk $=999279997 \&$ view $=$ c \& wchp=dGLbVlbzSkzS\&md5=0f0ec891edec60312497c79f81949700\&ie=/ sdarticle.pdf>. Acesso em: 21 jun. 2009. doi:10.1016/S03088146(00)00223-5. 
OLIVEIRA, M.D.L. et al. Purification of a lectin from Eugenia uniflora L. seeds and its potential antibacterial activity. Letters in Applied Microbiology, v.46, p.371-376, 2008. Disponível em: <http://repositorium.sdum.uminho.pt/bitstream/1822/ 7754/1/Oliveira_Lam\%5b1\%5d.pdf>. Acesso em: 21 jun. 2009. doi: $10.1111 / \mathrm{j} .1472-765 X .2007 .02319 . x$.

PURAVANKARA, D. et al. Effect of antioxidant principles isolated from mango (Mangifera Indica L.) seed kernels on oxidative stability of buffalo ghee (butter-fat). Journal of the Science of Food and Agriculture, v.80, p.522-526, 2000. Disponível em: <http://www3.interscience.wiley.com/ cgi-bin/fulltext/71001213/PDFSTART>. Acesso em: 21 jun. 2009. doi:10.1111/j.1472-765X.2007.02319.x.

REYNERTSON, K.A. et al. Quantitative analysis of antiradical phenolic constituents from fourteen edible Myrtaceae fruits. Food Chemistry, v.109, p.883-890, 2008. Disponível em: $<\mathrm{ht} \mathrm{t}$ : / / w w w s c i e n c e d i r e c t c o m / science?_ob=MImg\&_imagekey=B6T6R-4RMNYM1-9-

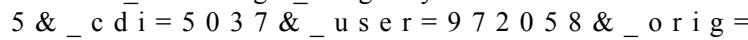
$\mathrm{se}$ a r c h \&_cover D a t e $=08 \% 2 \mathrm{~F} 15 \% 2 \mathrm{~F} 20$ $08 \&$ \& $\mathrm{k}=998909995 \& \mathrm{view}=\mathrm{c} \& \mathrm{wchp}=\mathrm{dGLbVlz}-$ zSkzV \&md5=7f0c121005317411 cfbbace8f936f19b\&ie=/ sdarticle.pdf $>$. Acesso em: 20 jun. 2009. doi: 10.1016/ j.foodchem.2008.01.021.

SPADA, P.D.S. et al. Antioxidant, mutagenic and antimutagenic activity of frozen fruits. Journal of Medicinal Food, v.11, p.144-151, 2008. Disponível em: <http://www.liebertonline.com/ doi/pdf/10.1089/jmf.2007.598>. Acesso em: 20 jun. 2009. doi: 10.1089/jmf.2007.598.

SUTER, P.M. Carbohydrates and dietary fiber. Handbook of Experimental Pharmacology, v.170, p.231-261, 2005.

SHAHID, F. et al. Phenolics antioxidants. Critical Reviews in Food Science and Nutrition, v.130, p.2073s-2085s, 1992.

SINGLETON, V.L.; ROSSI, J.A. JR. Colorimetry of total phenolic with phosphomolybdic-phosphotungstic acid reagents. American Journal of Enology and Viticulture, v.16, p.144$158,1965$.

SOOBRATTEE, M.A. et al. Phenolics as potential antioxidant therapeutic agents: Mechanism and actions. Mutation Resource, v.579, p.200-213, 2005. Disponível em: <http://www.sciencedirect.com/ science?_ob=MImg\&_imagekey=B6T2C-4GYP0KG-1-

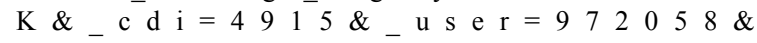

or ig $=$ s e a r c h \& c c o ver D a t e $=11 \% 2 \mathrm{~F} 11$ $\% 2$ F2005\& sk=994209998\&view $=\mathrm{c} \& \mathrm{wchp}=\mathrm{dGLbV} 1 \mathrm{~W}-$ zSkzV\&md $\overline{5}=95007 \mathrm{ad} 59135 \mathrm{~d} 097 \mathrm{dabd0835d4b646f7 \& \textrm {ie } = /}$ sdarticle.pdf $>$. Acesso em: 20 jun. 2009. doi: 10.1016/ j.mrfmmm.2005.03.023.

SOONG, Y.Y; BARLOW, P.J. Antioxidant activity and phenolic content of selected fruit seeds. Food Chemistry, v.88, p.411417, 2004. Disponível em: <http://www.sciencedirect.com/ science?_ob=MImg\&_imagekey=B6T6R-4BYNPMF-HC\&_cd $\bar{i}=5037 \&$ \& s e r $=972058 \&$ \& orig $=$ se a r c $\mathrm{h} \& \&_{-} \mathrm{c}$ o v e r D a t e = $\begin{array}{llllllllll} & 2 & \% & 2 & \mathrm{~F} & 3 & 1 & \% & 2 & \mathrm{~F}\end{array}$ $004 \& \quad \mathrm{sk}=999119996 \& \mathrm{view}=\mathrm{c} \& \mathrm{wchp}=\mathrm{dGLbVtz}-$ zSkzS\&md5=a6125947abefec681d4199782e732e4e\&ie=/ sdarticle.pdf>. Acesso em: 20 jun. 2009. doi: 10.1016/ j.foodchem.2004.02.003.

TAKECHI, M. et al. Structure and antiherpetic activity among the tannins. Phytochemistry, v.24, p.2245-2250, 1985.

TALCOTT, S.T. et al. Phytochemical composition and antioxidant stability of fortified yellow passion fruit (Passiflora edulis). Journal of Agricultural and Food Chemistry, v.51, n.4, p.935-941, 2003. Disponível em: <http:// pubs.acs.org/doi/pdf/10.1021/jf020769q>. Acesso em: 21 jun. 2009. doi: $10.1021 /$ jf020769q.

TRAITLER, H. et al. Characterization of ã-linolenic acid in Ribes seed. Lipids, v.19, p.923-928, 1984. Disponível em: $<$ http://www.springerlink.com/content/u4n046w0023tp071/ fulltext.pdf $>$. Acesso em: 28 jun. 2009. doi: 10.1007/ BF02534727.

YI, C. et al. Fatty acid composition and phenolic antioxidants of winemaking pomace powder. Food Chemistry, v.114, p.570576, 2008. Disponível em: <http://www.sciencedirect.com/ science? ob=MImg\& imagekey=B6T6R-4TN0M1B-3$9 \&$ \& cdi $=5037 \&$ \& user $=972058 \&$ \& orig = search \& c o v e r D a t e $=\begin{array}{llllllllllllll}0 & 5 & \% & 2 & \mathrm{~F} & 1 & 5 & \% & 2 & \mathrm{~F} & 2 & 0 & 0 & 9\end{array}$ _ s k $=998859997 \& \mathrm{view}=\mathrm{c} \& \mathrm{wchp}=\mathrm{dGLbVzz}-$ zSkWz\&md5 $=9480 \mathrm{c} 520 \mathrm{f} 20 \mathrm{cca} 53 \mathrm{f} 6 \mathrm{ac} 73 \mathrm{f} 0 \mathrm{a} 43 \mathrm{~b} 4 \mathrm{fce} \& \mathrm{ie}=/$ sdarticle.pdf $>$. Acesso em: 28 jun. 2009. doi: 10.1016/ j.foodchem.2008.09.103.

VINSON, J.A et al. Phenol antioxidant quantity and quality in foods: fruits. Journal of Agricultural and Food Chemistry, v.49, p.5315-5321, 2001. Disponível em: <http://pubs.acs.org/ doi/pdf/10.1021/jf0009293>. Acesso em: 28 jun. 2009. doi: $10.1021 /$ jf0009293. 